\title{
The Relevance of the ISO26000 Social Responsibility Issues to the Hong Kong Construction Industry
}

Lisa Robyn Barnes and Norman Croker, (University of Newcastle, Australia)

\begin{abstract}
Corporate Social Responsibility ("CSR"), the responsibility of a corporation for the impacts of its decisions on society and the environment, originated as a term in the 1950's (Carroll 1999). However, ISO 26000 "Guidance on Social Responsibility" published in November 2010, redefines "Social Responsibility" ("SR") broadly, by reference to SR principles, core subjects and issues. The Hong Kong Construction Industry ("HKCl") sector is critical to Hong Kong's economy, accounting for 5.6\% of the GDP and 9.2\% of employment in 1999 (Tang 2001). In 2011, the gross value of construction work amounted to $H K \$ 215.0$ billion and contributed HK\$65.4 billion (HKSARCSD 2013a) to the total GDP of HK\$1,823.2 billion (HKTDC 2013; HKGov 2013). Provisional quarterly data for 2012 indicates an increase in the gross value of construction works for 2012 of $25 \%$ to be now in excess of HK\$250 billion (HKSARCSD 2013b). The aim of this research is to investigate which ISO 26000 SR principles, core subjects and issues are relevant to $\mathrm{HKCl}$ firms. The principle findings are that: the reported level of $\mathrm{HKCl}$ CSR activity relative to the seven core subject of ISO 26000 is a function of company size; many SME's consider that many of the ISO 26000 SR issues are irrelevant to them; but for the large construction contractors, with employee numbers greater than 200, the SR issues in ISO 26000, particularly those relating to the health and safety in the workplace and to the environment, are not only relevant but in many cases the corporate SR activities exceed legislated requirements.
\end{abstract}

Keywords: Construction Industry, Corporate Social Responsibility

\section{Background}

Corporate Social Responsibility ("CSR"), as a term and concept, is quite modern although societal and academic interest in the business and society relationship has a long history. As a term, CSR's use has expanded greatly since its modern inception in the 1950's in America such that it is now well-established, not only in America but also world-wide, whereby:

"companies integrate social and environmental concerns in their business operations and in their interaction with their stakeholders on a voluntary basis" (Knopf et al. 2011, p. 9).

However, it remains an inherently complex and multifaceted concept (Cochran 2007), with a wide variety of meanings and numerous definitions, such that the term has been criticised as being a vague and unclear concept (Votaw 1972; Coelho, McClure \& Spry 2003). In America, CSR developed as an explicit activity, although in Europe "there was a tradition of CSR-relevant institutions (referred to as 'implicit CSR') long before the concept of CSR was discussed explicitly" (Knopf et al. 2011, p. 9). With the growth of globalisation, the American model expanded internationally for numerous reasons (Hatcher 2003; Chaudhri 2006; Jones 2009; Ahmad 2011). The expansion of CSR as a concept and management imperative globally has resulted in firms increasingly showing interest in, and reporting on, CSR as the concept matures and stakeholders increasingly demand such behaviour by firms, particularly over the last decade when various institutions and governments have produced CSR-related standards, guides and policies with over 400 CSR Standards now in place world-wide (Diao 2010). 


\section{Corporate Social Responsibility: ISO 26000}

The Social Responsibility ("SR") of an organisation is defined by the International Organisation for Standardization ("ISO") in ISO 26000 "Guidance on Social Responsibility", published in November 2010 (pp. 3-4) as the:

"responsibility of an organization for the impacts of its decisions and activities on society and the environment, through transparent and ethical behaviour that

- contributes to sustainable development, including health and the welfare of society;

- takes into account the expectations of individuals or groups that have an interest in any decision or activity of the organisation (stakeholders);

- is in compliance with the applicable law and consistent with international norms of behaviour; and

- is integrated throughout the organisation and practiced in its relationships".

ISO 26000 (2010) was qualified as being "not a management system standard [nor] intended or appropriate for certification purposes" (p. 1) and further defines SR broadly by reference to seven principles, seven inter-related core subjects and their 36 related SR issues (pp. 10$68)$, as shown in figure 1.

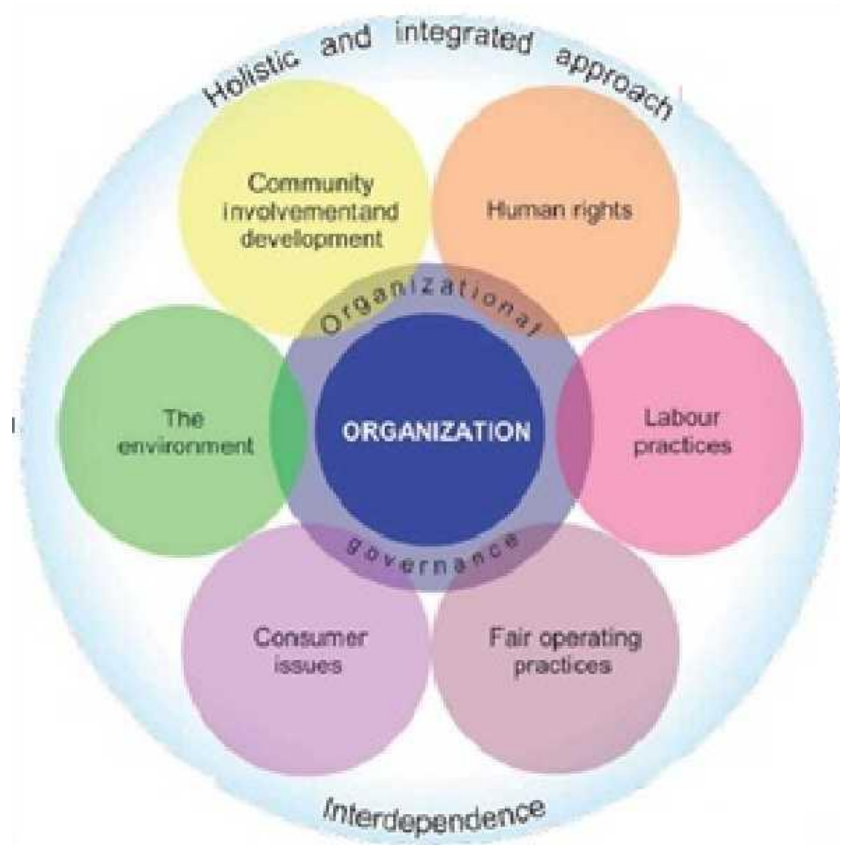

Figure 1 The inter-relationship of Seven Core Subjects (ISO 26000, 2010, p 20)

\section{The Hong Kong Construction Industry ("HKCl”)}

The construction industry ("Cl”) comprises:

"all those organisations and persons concerned with the process by which building and civil engineering works ... are procured, produced, altered, repaired, maintained and demolished. This includes companies, firms and individuals working as consultants, main and sub-contractors, material producers, equipment suppliers and builder's merchants. The industry has close relationships with clients and financiers" (CIB TG 29, 1998, Agreed International Definition in Hillebrandt 2000, p. 4).

Although the $\mathrm{Cl}$ is economically important, its process are geographically and functionally fragmented (O'Brien \& Al Soufi 1993); it is "motivated by turnover, profit and shareholder 
returns"; and slow to adopt CSR (Murray \& Dainty 2007 p. 3). Indeed, it is the Cl's product characteristics, being large heavy and expensive; the separation of design from construction; and the method of price determination, generally through tendering and negotiation; which determine the structure of the industry and its geographical and functional fragmentation (Hillebrandt 2000, p. 5).

The $\mathrm{Cl}$ is important world-wide because (a) its product is large and therefore significant to the world's economies; (b) it produces investment goods which can contribute to world economic well-being; and (c) infrastructure construction is vital for development, particularly in developing countries (Hillebrandt 2000). The $\mathrm{HKCl}$ is critical to Hong Kong's economy, accounting for $5.6 \%$ of the GDP and $9.2 \%$ of employment in 1999 (Tang 2001), which fell to $3.2 \%$ of GDP in 2004, following the SARS pandemic but has subsequently recovered (Rowlinson 2007). HKCl activities are labour-intensive, dangerous and polluting; it is fragmented; adversarial and employs non-value adding multi-layered subcontracting (Tang 2001). The $\mathrm{HKCl}$ is characterized by a small number of large local and overseas contractors which depend on sub-contracting (Rowlinson 2007), a practice that can dissipate espoused CSR policies (Green 2007).

\begin{tabular}{|c|c|c|c|c|c|c|c|}
\hline $\begin{array}{l}\text { Gross value } \\
\text { of } \\
\text { construction } \\
\text { works } \\
\text { performed } \\
\text { HK\$ M }\end{array}$ & $\begin{array}{l}\text { No. of } \\
\text { establish- } \\
\text { ments } \\
\text { (\% of Total) }\end{array}$ & $\begin{array}{c}\text { Number of } \\
\text { persons } \\
\text { directly } \\
\text { engaged } \\
\text { (Ave. No) }\end{array}$ & $\begin{array}{l}\text { Payments } \\
\text { to } \\
\text { employees } \\
\text { and labour- } \\
\text { only sub- } \\
\text { contractors } \\
\text { HK\$ M }\end{array}$ & $\begin{array}{c}\text { Consumption } \\
\text { of materials, } \\
\text { supplies, } \\
\text { utilities, \& } \\
\text { fuels, etc, } \\
\text { HK\$ M }\end{array}$ & $\begin{array}{l}\text { Payment to } \\
\text { fee sub- } \\
\text { contractors } \\
\text { HK\$ M } \\
\text { (Ave \% of } \\
\text { gross) }\end{array}$ & $\begin{array}{l}\text { Miscell- } \\
\text { aneous } \\
\text { operating } \\
\text { expenses } \\
\text { HK\$ M }\end{array}$ & $\begin{array}{l}\text { Gross value of } \\
\text { construction } \\
\text { works } \\
\text { performed } \\
\text { HK\$ M }\end{array}$ \\
\hline $0-9,999$ & $\begin{array}{c}20,849 \\
(89.0 \%)\end{array}$ & $\begin{array}{c}71,045 \\
(3.4)\end{array}$ & 3,435 & 5,220 & $\begin{array}{c}5,044 \\
(27.2 \%)\end{array}$ & 963 & 15,452 \\
\hline $\begin{array}{c}10,000- \\
19,999\end{array}$ & $\begin{array}{c}1,789 \\
(7.6 \%)\end{array}$ & $\begin{array}{c}22,684 \\
(12.7)\end{array}$ & 4,835 & 5,587 & $\begin{array}{c}7,915 \\
(35.5 \%)\end{array}$ & 1,930 & 22,294 \\
\hline $\begin{array}{c}20,000- \\
49,999\end{array}$ & $\begin{array}{c}294 \\
(1.3 \%)\end{array}$ & $\begin{array}{c}13,412 \\
(45.6)\end{array}$ & 4,767 & 2,696 & $\begin{array}{c}1,485 \\
(12.7 \%)\end{array}$ & 823 & 11,671 \\
\hline $\begin{array}{l}50,000- \\
99,999\end{array}$ & $\begin{array}{c}281 \\
(1.2 \%)\end{array}$ & $\begin{array}{c}19,395 \\
(69.0)\end{array}$ & 5,270 & 3,757 & $\begin{array}{c}7,754 \\
(40.5 \%)\end{array}$ & 1,144 & 19,144 \\
\hline $100,000+$ & $\begin{array}{c}203 \\
(0.9 \%)\end{array}$ & $\begin{array}{l}43,809 \\
(215.8)\end{array}$ & 21,874 & 21,084 & $\begin{array}{c}61,394 \\
(53.0 \%)\end{array}$ & 9,167 & 115,870 \\
\hline Total & 23,417 & 170,345 & 50,625 & 44,400 & $\begin{array}{c}91,082 \\
(42.4 \%)\end{array}$ & 17,540 & 214,976 \\
\hline
\end{tabular}

Table 1 Principal statistics for the construction sector by gross value of works performed, 2011 (All figures in HK\$ millions) (Source: HKSARCSD 2013a, p. 13)

Most sub-contracting firms in the $\mathrm{HKCl}$ are part of the small to medium ("SME") sector, which accounts for $98 \%$ of Hong Kong's business establishments, defined as "economic units under a single owner or control in one kind of economic activity" (HKSARCSD 2013a, p. 42). As shown in Table 1, in the construction industry, only $2 \%$ of all firms have a gross value of construction works exceeding HK\$ 50 million ( $£ 4.2$ million) and average employee numbers greater than 50 . The remainder, on average would be "small to medium firms". Less than $1 \%$ of firms have a gross value of construction works exceeding HK\$100 million, but they account for $54 \%$ of the gross value of construction works performed; they subcontract $54 \%$ of their works to fee sub-contractors and, on average, would be "large firms" with employee numbers exceeding 200 . Similarly, firms having a gross value of construction works between HK\$ 50 to 100 million account for a further $9 \%$ of the gross value of construction works performed, sub-contract $40 \%$ of their works to fee sub-contractors and, on average, would be "medium" with employee numbers between 50 and 100 (HKSARCSD 2013a). If it is assumed that the gross value of sub-contracted works (HK\$ 91 million) is subcontracted to firms in the HK\$0 to 50 million per annum category, then the actual value of work directly performed by this sector amounts to $2 / 3^{\text {rds }}$ of the total gross value of

Barnes, L R and Croker, N (2013) 'The relevance of the ISO26000 social responsibility issues to the Hong Kong construction industry', Australasian Journal of Construction Economics and Building, 13 (3) 37-50 
construction work. Thus, at least $98 \%$ of construction industry firms fall in the category of SME firms and account for at least $65 \%$ of the gross value of construction works performed (albeit with the majority of that value being as sub-contractors to medium or large firms). However, most existing efforts to engage Hong Kong's SME's in environmental and social performance issues have had little impact on SME's to date (Studer et al. 2008).

\section{SME's and CSR}

During the past decade, the evolving CSR literature, and the imperatives of increased requirements for accountability and sustainability moved the main discussion from a "whether or not to" to a "how to" implement CSR debate, but this debate has primarily centred on large firms with very little focus on SME's, on the implicit assumption that small businesses are essentially the same as big businesses but on a smaller scale. Welsh and White (Welsh \& White 1981, p. 18) argued some time ago that "a small business is not a little big business" due to small business's "resource poverty", arising primarily out of: a tendency to be in highly fragmented, very competitive industries; inability to afford professional staff; higher relative cost to comply with legislated regulations; and, severe restraints to raise finances, all of which issues can be attributed to SME's in the Cl. Although few articles have explored this difference between SME's and large businesses during the interim 30 years have been identified, it was recently argued that stakeholder theory might generally be appropriate for CSR research in large corporations but it is inapplicable for SME's for which resource theory /social capital principles are more appropriate (Perrini 2006; Perrini, Russo \& Tencati 2007; Russo \& Perrini 2010)

\section{The Relevance of ISO 26000 (2010) SR issues to the Cl: a Research Problem}

Although there are, as yet, but a few journal articles that address the recent publication of ISO 26000 ( $n=21$ to 2012), it has been found that "the most important barrier and difficulty for CSR implementation is the general lack of knowledge or awareness of CSR [in Iran]" (Valmohammadi 2011, p. 260). Moreover, there is a paucity of articles which address CSR in the $\mathrm{HKCl}$, although it is a very important industry for many national economies. No articles identifying which issues are important for individual industries by reference to a large sample population have been identified. This research will investigate the level of knowledge and awareness of CSR in the $\mathrm{HKCl}$ by reference to ISO 26000 (2010), and by reference to all available $\mathrm{HKCl}$ companies in publicly available lists and for which postal addresses can be readily identified.

Therefore, the focus of this research is to fill the literature gap relating to $\mathrm{Cl}$ practitioners' perceptions of which CSR issues identified in ISO 26000 (2010), if any, are applicable to the $\mathrm{HKCl}$. This leads to the Research Problem of:

How does, and what is the extent to which, CSR as now defined by ISO 26000 apply to CI firms, particularly to $\mathrm{HKCl}$ firms?

The relevant factors identified in the literature generate the following research question and hypothesis:

RQ1 To what extent do $\mathrm{HKCl}$ firms and their management consider that $\mathrm{HKCl}$ firms are meeting or exceeding their legislated and voluntary CSR obligations as described in ISO 26000 (2010)?

$\mathrm{RH} 1$ Large (or main contractor) $\mathrm{HKCl}$ firms and their management consider that $\mathrm{HKCl}$ contractors currently meet but do not exceed legal obligations except in the specific areas of health and safety. 


\section{Methodology}

Mauch and Birch (1998, pp. 116-122), identify 19 'methodologies' including the five 'research strategies' used in the social sciences as described by Yin (2003) of: experiments, surveys, archival analysis, histories and case studies. Fellows and Liu (2003) assert that the majority of research in the social sciences and management spheres involves two of these strategies, being questionnaire surveys and case studies. From these conditions, the survey approach is applicable to "who, what, where, how many and how much" questions and the case study approach is applicable to "why and how" questions (Yin 2003, p. 5). RQ1 falls in the category of "how many and how much" and requires original empirical data to be sourced; and, a nomothetic style questionnaire methodology is appropriate. Therefore, the adopted methodology consisted of a questionnaire to a broad cross section of predominantly contractors and sub-contractors from lists of $\mathrm{HKCl}$ firms identified on publicly available websites.

\section{Establish the Survey Frame and the Sample Population}

Hong Kong is a Special Administrative Region of the People's Republic of China and a very high density city-state with a well-advanced and organised $\mathrm{Cl}$, subject to a degree of government regulation. To large extent, then, Hong Kong forms the area frame for the study. There are a number of organisations that maintain publically available lists of $\mathrm{Cl}$ firms on their websites. The target population for the questionnaire survey was therefore decided to be the senior management of those $\mathrm{HKCl}$ listed on such organisations' websites. Among these, the Hong Kong Construction Association Ltd. ("HKCA"), with a membership of approximately 320 contractors is the peak body for the industry. A separate body, the Hong Kong Federation of Electrical and Mechanical Contractor Ltd. ("HKFEMC") with a membership of approximately 150 represents the specialist (generally smaller) contractors in those specialist disciplines. Other organisations include the Hong Kong General Building Contractors Association ("HKGBCA"), the Hong Kong Bar-bending Contractors Association, the Hong Kong Electrical Contractors Association, the Hong Kong Construction SubContractors Association ("HKCS-CA") and so on. Some of these associations maintain websites and some do not. The Hong Kong Construction Industry Council ("HKCIC") is a government legislated peak body for the $\mathrm{Cl}$ in Hong Kong responsible, in part, for industry training and administration and maintains a list of "Voluntary Registered Sub-Contractors" ("VRS", subsequently renamed "list of Registered Sub-Contractors)".

In addition, the Hong Kong Government's Works Bureau ("Works Bureau") maintains a register of approximately 250 contractors which are pre-qualified to tender for government projects. This register encompasses contractors which are registered to tender for projects with a value less than $\mathrm{HK} \$ 20$ million (Class $A$ ), between $\mathrm{HK} \$ 20$ million and $\mathrm{HK} \$ 50$ million (Class B) and greater than HK\$ 50 million (Class C). A separate register of approximately 500 contractors, which are pre-qualified to tender for specialist projects and as subcontractors for the specialist elements of larger projects as sub-contractors to main contractors, is maintained by the Works Bureau. Some contractors are listed on both registers and some are also members of the HKCA and the HKFEMC, or both associations, and some are also $\mathrm{HKClC}$ registered sub-contractors. Of the other associations, most of the members listed on the websites which were available (such as the HKGBCA) were included in the other lists and /or for the remainder, identifying their postal addresses proved to be prohibitively time-consuming and they were not included as a source of potential invitees. Others, such as the HKCS-CA either had no website or no member lists.

A combined dataset of the members of the HKCA, the HKFEMC, the contractors listed on both registers of the Works Bureau, those listed in the HK Yellow Pages ("HKYP") and those identified in the HKCIC VRS register formed the list frame for the research and those who responded formed the sample population. Thus, there is an element of convenience

Barnes, L R and Croker, N (2013) 'The relevance of the ISO26000 social responsibility issues to the Hong Kong construction industry', Australasian Journal of Construction Economics and Building, 13 (3) 37-50 
sampling but the sampling also includes an element of volunteer sampling in that not all the potential invitees "volunteered to respond".

\section{Background to the Analysis}

The questions for the questionnaire were designed from first principles to gauge the relevance of each of the core issues in ISO 26000 (2010). In addition to the 44 questions relating to the seven principles and seven core subjects of ISO 26000 (2010), seven demographics questions were developed to potentially permit analysis of different segments, company types and position-related views. One question related to company size to potentially differentiate between large business views and actions on CSR and those of SME's. Different countries classify small and medium sized businesses by different "head count" numbers. Therefore this question aimed to permit comparison between sizes consistent with Australia (Small Enterprise < 20; Medium Enterprise < 200 (ABS 1999)), the European Union and the UK (Small Enterprise < 50; Medium Enterprise < 250 (EC 2003)), and Hong Kong (Small and Medium Enterprise (Manufacturing) < 100; Small and Medium Enterprise (Non-manufacturing) < 50 (HKSARCSD 2013a)).

Therefore, the initial dissemination was through the HKCA to its members and subsequent disseminations of questionnaires to the companies on the other lists were performed by the researchers. The purpose was primarily exploratory as there is little (or no) existing literature which investigates the relative importance of factors for and against adopting CSR practices in the $\mathrm{Cl}$ (or the $\mathrm{HKCl}$ ) and none that explores the relevance of ISO 26000 (2010) to the $\mathrm{Cl}$.

\section{Quantitative Study - HKCI Questionnaire}

An initial review of the number of publicly available lists of $\mathrm{HKCl}$ companies on the websites of the HKCA (HKCA 2012), the HKFEMC (HKFEMCL 2012) the Works Bureau's Lists (HKGDevB 2012) and the HKYP (HKYP 2012) was performed to determine how many HKCl contracting firms would be reasonably accessible, in that their particulars (names and phone numbers as a minimum) were available. Some of the large international $\mathrm{Cl}$ firms are not listed on the Hong Kong Stock Exchange and it is, therefore, not a reliable source of identification of large $\mathrm{Cl}$ firms. The lists contained by these organisations contain many duplicates, both internally due to companies being listed in several sub-categories and externally between the lists. In order to estimate the number of $\mathrm{Cl}$ firms, each list was carefully examined and all duplicates removed with the resultant expected sample population estimated to be approximately 1,900. It should be noted that, because the firms in the first 4 lists in Table 2, below, account for nearly all the larger $\mathrm{HKCl}$ firms, those in the HKYP and HKCIC VRS (HKCIC 2012) lists are almost exclusively SME's.

\begin{tabular}{|l|c|c|c|}
\hline \multicolumn{1}{|c|}{ Name of List } & Number in List & $\begin{array}{c}\text { Duplicated / no } \\
\text { postal address }\end{array}$ & Net number in list \\
\hline HKCA & 320 & - & 320 \\
\hline HKFEMCL & 148 & - & 148 \\
\hline HKGDevB: Contractors & 259 & $146 / 0$ & 113 \\
\hline HKGDevB: Specialists & 553 & $190 / 0$ & 363 \\
\hline HKYP: Construction Contractors & 1,555 & $435 / 300$ & 820 \\
\hline HKCIC VRS & $\sim 7,000$ & $\sim 5,911$ & 1,089 \\
\hline Totals & $\sim 9,835$ & $\sim 6,982$ & 2,853 \\
\hline
\end{tabular}

Table 2 List of Contractors in public domain issued with invitations to participate

Assuming $85 \%$ of the listed companies could be contacted, and a response rate of approximately $10 \%$ could be achieved, then this would achieve the targeted total of 150 . However, even if the result was at $5 \%(n=75)$ it was considered that this would be sufficient based on an effective 1-5 rating scale (range of 4 units) divided by 4 on the assumption of a normal distribution divided by (say) a precision of $1 / 4$ unit using the formula minimum sample

Barnes, L R and Croker, N (2013) 'The relevance of the ISO26000 social responsibility issues to the Hong Kong construction industry', Australasian Journal of Construction Economics and Building, 13 (3) 37-50 
size $=\left[(\text { degree of confidence }\{95 \%\} \times \text { variability }\{\text { range } / 4\} / \text { desired precision }\{1 / 4 \text { unit }\}]^{2}\right.$ (Hair et al. 2003, p. 219): $\left[\left(2^{*} 1\right) /(0.25)\right]^{2}=64$.

\begin{tabular}{|c|c|c|c|c|}
\hline Source of List & English & Chinese & Discard & Total \\
\hline \multicolumn{5}{|c|}{ Hong Kong Construction Association $(n=320-4.70 \%)$} \\
\hline Hard Copy Response & 6 & 3 & & 9 \\
\hline Web-based Electronic Response & $(8-5=3)$ & $(6-3=3)$ & 8 & 14 \\
\hline Net Total & 9 & 6 & 8 & 23 \\
\hline \multicolumn{5}{|c|}{ Federation of Electrical and Mechanical Contractors $(n=148-10.81 \%)$} \\
\hline Hard Copy Response (including email) & $(7-1=6)$ & 7 & 1 & 14 \\
\hline Web-based Electronic Response & $(3-1=2)$ & $(3-2=1)$ & 3 & 6 \\
\hline Net Total & 8 & 8 & 4 & 20 \\
\hline \multicolumn{5}{|c|}{ HK Gov't List of Approved Contractors $(n=113-7.08 \%)$} \\
\hline Hard Copy Response & $(3-2=1)$ & $(5-1=4)$ & 3 & 8 \\
\hline Web-based Electronic Response & 2 & $(4-3=1)$ & 3 & 6 \\
\hline Net Total & 3 & 5 & 6 & 14 \\
\hline \multicolumn{5}{|c|}{ HK Gov't List of Approved Specialist Contractors \& Suppliers $(n=363-4.96 \%)$} \\
\hline Hard Copy Response & 5 & $(14-1=13)$ & 1 & 19 \\
\hline Web-based Electronic Response & 0 & 0 & 0 & 0 \\
\hline Net Total & 5 & 13 & 1 & 19 \\
\hline \multicolumn{5}{|c|}{ HK YP \& CIC-VRS (Combined $n=1,909-4.03 \%)$} \\
\hline Hard Copy Response & 24 & $56(-9)$ & 9 & 80 \\
\hline Web-based Electronic Response & $(5-3=2)$ & $(6-2=4)$ & 5 & 11 \\
\hline Net Total & 26 & 51 & 14 & 91 \\
\hline Hard copy $(n=116 / 2,853,-4.07 \%)$ & 42 & 74 & 14 & 130 \\
\hline Web base $(n=18 / 855-2.11 \%)$ & 9 & 9 & 19 & 37 \\
\hline Total $(n=134 / 2,853-4.70 \%)$ & 51 & 83 & 33 & 167 \\
\hline
\end{tabular}

Table 3 Schedule of responses from Survey

In all, 2,853 invitations to participate were posted, as shown in Table 2. As can be seen from Table 2, the number for which no postal address could be found for the HKYP was far greater than the assumed $15 \%$. In fact, most of the addresses for the HKYP entries were found through the HKCIC VRS list. Therefore, for both the HKYP and HKCIC VRS mailing lists, which were prepared together, the governing parameter became whether the entries identified that the entry represented a "sole trader" or an "unincorporated business name". All such entries were discarded on the basis that they did not represent "corporations" as were entries for which only residential as opposed to commercial addresses were found. 960 follow-up emails were issued and 105 automatic responses were received from "Postmaster" that the emails were not deliverable to the nominated email addresses, leaving a net 855 apparently delivered emails. 129 hardcopy responses, 1 email response and 37 websurveys were received. Three response envelops were received with contents apparently intended for someone else. Most of the hardcopy responses were very well and fully completed. However, 11 were either incomplete or a single column was checked for all

Barnes, L R and Croker, N (2013) 'The relevance of the ISO26000 social responsibility issues to the Hong Kong construction industry', Australasian Journal of Construction Economics and Building, 13 (3) 37-50 
answers and were discarded. Similarly, although the surveytool was configured to require all answers to be completed prior to moving to the next "sheet" just over half the web-surveys were "drop-outs" meaning that the respondent had partially completed it and exited and these were also discarded. Therefore, the final net response number was 134 (1 email, 115 hardcopy and 18 web-surveys) for a total of $4.70 \%$, as tabulated below.

Although the smaller number of the web-based survey responses showed greater variability, the trend line was, by inspection, exactly the same and so the two files were exported to Microsoft Excel and combined.

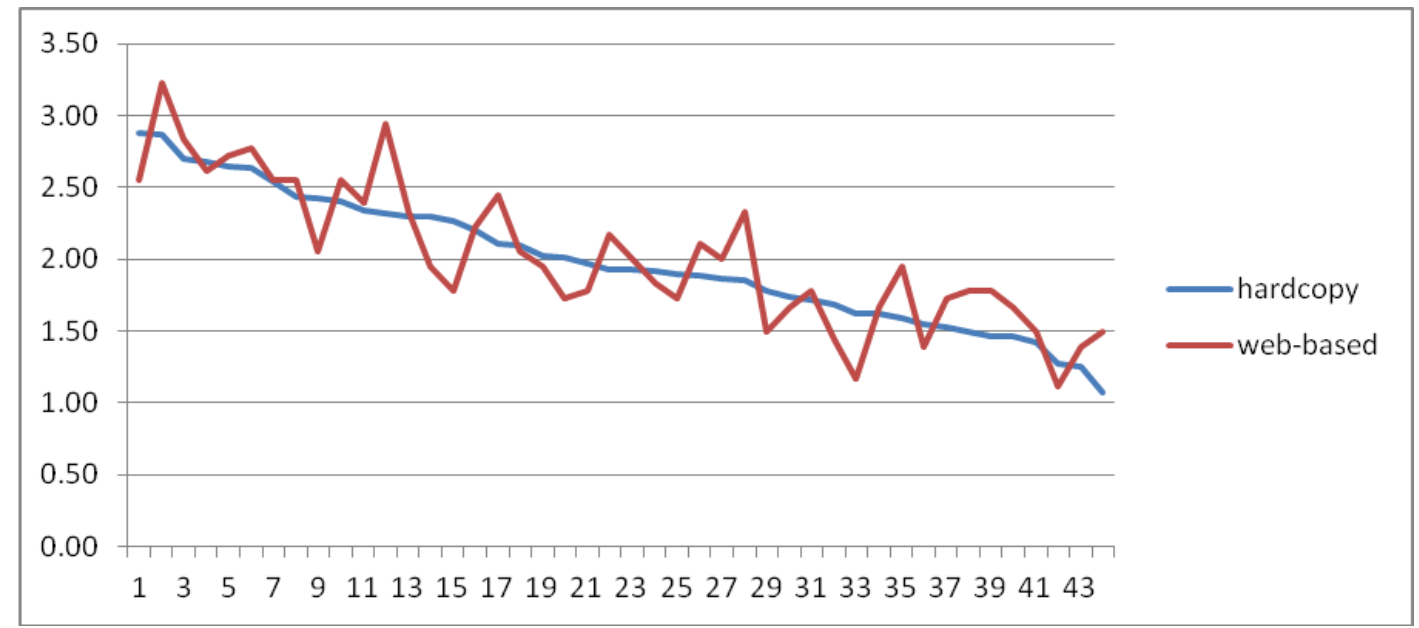

Figure 2 Comparison of hardcopy $(n=116)$ and web-based $(n=18)$ responses

The CSR principles together with core subject \#1, Corporate Governance, and the six remaining CSR core subject incorporated into ISO 26000 (2010) and the questionnaire, can be used to form seven "constructs" or concepts from the elements comprising the questions in those sections to test which sections are, in the views of the respondents, more or less relevant to the $\mathrm{Cl}$. These were identified and used as the variable names, and the labels and values were then assigned. Decimal definition was set at 0 ; there was no incorrect data; there were no incorrectly coded items and no negatively worded items.

The 8 variables representing the responses in relation to Principles; 8 variables representing Human rights; 5 variables representing Labour practices; 4 variables representing Environmental practices; 5 variables representing Fair operating practices; 7 variables representing Consumer issues; and the 7 variables representing Community issues; being each of the seven potential constructs were examined. Each set was tested using Analyse $\rightarrow$ Scale $\rightarrow$ Reliability Analysis and can be summarised as follows:

\begin{tabular}{|l|r|r|r|r|r|r|r|}
\hline & $\begin{array}{c}\text { Principles } \\
\text { (Including } \\
\text { Governance) }\end{array}$ & $\begin{array}{c}\text { Human } \\
\text { Rights }\end{array}$ & $\begin{array}{c}\text { Labour } \\
\text { Practices }\end{array}$ & Environment & $\begin{array}{c}\text { Fair } \\
\text { Operating } \\
\text { Practices }\end{array}$ & $\begin{array}{c}\text { Consumer } \\
\text { Issues }\end{array}$ & $\begin{array}{c}\text { Community } \\
\text { Involvement }\end{array}$ \\
\hline $\begin{array}{l}\text { N of Cases } \\
\text { (Excluded) }\end{array}$ & 134 & 134 & 134 & 134 & 134 & 134 & 134 \\
\hline N of Items & 8 & 8 & 5 & 4 & 5 & 7 & 7 \\
\hline Alpha & 0.895 & 0.911 & 0.857 & 0.820 & 0.807 & 0.903 & 0.894 \\
\hline
\end{tabular}

Table 4 Summary of Reliability Scales for 7 Constructs (Alpha)

Barnes, L R and Croker, N (2013) 'The relevance of the ISO26000 social responsibility issues to the Hong Kong construction industry', Australasian Journal of Construction Economics and Building, 13 (3) 37-50 
A review of the statistics in Table 4 and the Item-Total statistics shows that all of the Cronbach's Alpha figures for the 7 constructs indicate that there is "very good" correlation for combining the variables in each construct to form a single construct variable $(0.8<0.9)$ or "excellent" (> 0.9) (Hair et al. 2003, p. 172). Review of the Item-total statistics for each of the constructs revealed that, eliminating only impacts of biodiversity for the Environment $(0.820$ to 0.821 ) and health impacts for Community issues (0.894 to 0.898 ) improved the Cronbach's Alpha. The decision was made not to delete these items at this stage of the analysis. Review of the Inter-Item Correlation Matrix revealed that the vast majority of all inter-item relationships were above 0.3 .

\section{Testing of the Seven Constructs}

Each of the 7 constructs were examined.

Firstly assumptions were tested.

\section{i. Sample size}

The sample size of 5 per variable and over 100 subjects (to be acceptable) criteria are both met (Coakes \& Steed 2007, p. 123).

\section{ii. Normality, Linearity and Outliers}

The data was tested individually for these assumptions. A number of the variables were found to be skewed, some quite heavily skewed (Principle5, Labour4, Labour5 and Practices2) However, Factor analysis is robust for normality and therefore these variable were not adjusted (Coakes \& Steed 2007). Six variables contained between 4 and 8 outliers. The total number of outlier cases amounted to 28 with 6 cases appearing twice, 2 cases appearing 3 times. However, rather than removing all of these cases from the data set they were retained. Linearity is assumed as per Coakes and Steed (2007, p. 123).

\begin{tabular}{|lllllllll|}
\hline Job description & 77 & 78 & 83 & 86 & 92 & 96 & 130 & 131 \\
Project work & 94 & 96 & 111 & 129 & & & & \\
Internal discipline & 94 & 97 & 111 & 129 & & & & \\
Infringement of rights & 97 & 112 & 121 & 131 & & & & \\
Social dialogues & 82 & 84 & 85 & 86 & & & & \\
Political involvement & 94 & 120 & 121 & 131 & & & & \\
\hline
\end{tabular}

Table 5 List of outliers in the data

\section{Testing the Relationship between the Constructs and overall CSR}

To test the relationship and whether all the constructs are significantly related to each other, liner regression was used sequentially to determine the relationship of each of the seven constructs to the other six constructs using Analyse $\rightarrow$ Regression $\rightarrow$ Linear and then again in a stepwise sequence to test the contributing relationship for the seven constructs to overall CSR performance; then the seven constructs were analysed using Analyse $\rightarrow$ Correlate. It was found that Human Rights and Labour Practices are the strongest indicators for CSR Principles; Operating Practices and CSR Principles are the strongest indicators for Human Rights; the Environment and CSR Principles are the strongest indicators for Labour Practices; Labour Practices and Operating Practices are the strongest indicators for the Environment; Human Rights and the Environment are the strongest indicators for Operating Practices; Operating Practices and the Community are the strongest indicators for Consumers; and Consumers and the Environment are the are the strongest indicators for 
the Community. All constructs are correlated to each other. CSR Principles and Human Rights issues are the strongest indicators /contributors to overall CSR performance.

\section{Is overall CSR dependent on Size or Company Type?}

The combined construct was then tested as the dependent variable against both size and company type using SPSS 14 Analyse $\rightarrow$ General Linear $\rightarrow$ Model Univariate. The results indicated that the reported degree of corporate social responsibility was dependent on size of the respondent's company and not whether the respondent was working for a main contractor or a subcontractor $F=5.212$.

\begin{tabular}{|l|r|r|r|r|r|}
\hline \multicolumn{1}{|c|}{ Source } & $\begin{array}{c}\text { Type III Sum of } \\
\text { Squares }\end{array}$ & \multicolumn{1}{c|}{ df } & Mean Square & \multicolumn{1}{c|}{ F } & \multicolumn{1}{c|}{ Sig. } \\
\hline Corrected Model & $57021.911(b)$ & 21 & 2715.329 & 2.325 & .002 \\
\hline Intercept & 380101.151 & 1 & 380101.151 & 325.485 & .000 \\
\hline Size & 24345.045 & 4 & 6086.261 & 5.212 & .001 \\
\hline Company & 1296.784 & 4 & 324.196 & .278 & .892 \\
\hline Size * Company & 9635.044 & 13 & 741.157 & .635 & .820 \\
\hline Error & 130793.522 & 112 & 1167.799 & & \\
\hline Total & 1261726.000 & 134 & & & \\
\hline Corrected Total & 187815.433 & 133 & & & \\
\hline
\end{tabular}

a Computed using alpha $=.05$

b R Squared $=.304$ (Adjusted R Squared $=.173$ )

Table 6 Tests of Between-Subjects Effects Dependent Variable: All_responses

\section{Demographics}

Respondents were also asked to provide their name, organisation type and size, job title or position, respondent's position, age, education and profession, and nearly all obliged. The 134 respondents were classified accordingly. Age was classified as 20-40, 40-50 and over 50 and using the median for each grouping as the average, the average age for the main study population was 49. Sub-contractors (59) and Main contractors (42) accounted for $75 \%$ of the employer types. 47\% (64) were employed by organisations with less than 50 employees and 25\% (34) were employed by organisations with more than 200 employees. Engineers accounted for nearly $40 \%$ of the respondents but most (74) reported "other". Nearly all (129) were qualified to Higher Certificate level, 118 reported that they were involved in project work.

Of interest, is that the data collection into descriptive statistics evidences that:

1 Labour practices issue - Occupational Health and Safety scores highest and is the only issue when the averages score of those who considered it a relevant issue $(n=130)$ is higher than the legal compliance of "Incorporates". The other two issues of Legally Recognised Employees and Skills Training for Employees are the next two highest issues.

2 Labour Practices overall with a score (mean) of 2.86 and an average of 128 respondents considering the construct overall to be relevant was the highest scoring construct. Consistent with the UK and Australian studies (Jones, Comfort \& Hillier 2006; Petrovic-Lazarevic 2008), the Environment's first two issues of reducing pollution and reducing waste are rated very highly but the greenhouse gasses and biodiversity items have the effect of lowering the overall rating of the Environment to make Consumers, surprisingly, the next most relevant construct, apparently on the basis that the $\mathrm{HKCl}$ respondents have taken the next entity up the "construction food chain", i.e. their client, as the consumer and rated fair trading, dispute resolution and safety highly.

Barnes, L R and Croker, N (2013) 'The relevance of the ISO26000 social responsibility issues to the Hong Kong construction industry', Australasian Journal of Construction Economics and Building, 13 (3) 37-50 
3 The construct that the respondents rated as least relevant was community involvement with $31 \%$ responding (on average, $n=42$ ) that the issues forming this construct are irrelevant, although Fair Operating Practices (particularly relating to political involvement and Property rights) had the overall lowest average.

\begin{tabular}{|l|c|c|c|c|r|c||}
\hline \multicolumn{1}{|c|}{ ISO 26000 Classifications } & $\begin{array}{c}\text { Less than } \\
\mathbf{2 0}\end{array}$ & $\mathbf{2 0}$ to 50 & $\mathbf{5 0}$ to 100 & $\mathbf{1 0 0}$ to 200 & Over 200 & $\begin{array}{c}\text { All } \\
\text { responses }\end{array}$ \\
\hline & & & & & & \\
\hline SR Principles & 2.15 & 2.55 & 2.67 & 2.84 & 3.11 & 2.65 \\
\hline Human Rights & 1.83 & 1.86 & 2.26 & 1.99 & 2.41 & 2.09 \\
\hline Labour Practices & 2.43 & 2.82 & 2.93 & 2.85 & 3.28 & 2.86 \\
\hline Environment & 2.03 & 2.42 & 2.70 & 2.44 & 3.09 & 2.57 \\
\hline Fair Operating Practices & 1.69 & 2.12 & 2.23 & 2.27 & 2.87 & 2.25 \\
\hline Consumer Practices & 2.26 & 2.54 & 2.72 & 2.47 & 3.16 & 2.66 \\
\hline Community Involvement \& Develop't & 1.93 & 2.16 & 2.23 & 2.44 & 2.70 & 2.30 \\
\hline \hline Survey totals & $\mathbf{2 . 0 6}$ & $\mathbf{2 . 3 5}$ & $\mathbf{2 . 5 3}$ & $\mathbf{2 . 4 6}$ & $\mathbf{2 . 9 3}$ & $\mathbf{2 . 4 8}$ \\
\hline
\end{tabular}

Table 7 CSR Grading (mean) by classification summary of responses

\section{Comparison between SME to Large Companies}

Table 8 shows the mean scores for each of the constructs and demonstrates and supports the major findings of this research, being that the reported level of CSR activity is a function of size of company and not necessarily a function of whether the company is a main contractor or a subcontractor, the major findings of this project,. Surprisingly the "100 to 200" employees group scored lower than the " 50 to 100 " employees group in Human Rights, Labour Practices, The Environment and Consumer Practices leading to an overall lower result. However, the results support the statistical analysis of the seven constructs that the independent variable is size alone.

For companies with an employee base of more than 200, the overall mean score is 2.93 ("Fully incorporates ISO 26000 issues, on average") and four of the constructs are between incorporates and exceeds - indicating going beyond the expected /legal requirements. On the other end of the scale, for companies of with less than 20 employees, the overall mean score is 2.06 (just "Accepts") and three of the constructs are below "Accepts".

In summary, this analysis has identified that the large contractors with employee numbers greater than 200, including the large sub-contractors, consider that they currently meet legal obligations and actually do exceed legal obligations in the specific area of health and safety but although there is a focus on environmental matters it is generally driven by compliance. In doing so it has answered Research Question RQ1 and found support for the primary component of Research Hypothesis $\mathrm{RH} 1$ in respect of the differentiating factor being size but not whether the company is a main contractor or a sub-contractor. The differentiating factor identified in this research is solely to do with corporate size.

\section{Discussion, Contribution and Suggestions}

Many of the issues identified in ISO 26000 are relevant to the $\mathrm{Cl}$ in Hong Kong. However, as noted by ISO 26000 itself, not all of the issues and core subjects are perceived as being relevant by all of the industry segments. In particular, most of the human rights issues were found to be not relevant to many of the respondents. The survey respondents, unexpectedly, rated the CSR issues associated with consumer issues relatively highly. This would appear to be because the $\mathrm{Cl}$ relationships are almost exclusively contractual up and down the supply chain. It would appear that the respondents to the survey interpret the consumer or 
customer as being the next client up the supply chain and have rated the issues to do with dispute resolution particularly and dealing with complaints from their "consumers" very highly.

However, although ISO 26000 only has one issue to do with safety in employment, this single issue scored most highly. Another focus of the respondents was environmental performance, but there was only minor perceived relevance to the issues of greenhouse gases and biodiversity. This research has clarified to an extent the findings of Jones et al. (2006) that the fiercely competitive nature of the $\mathrm{Cl}$ generates a focus on profit maximisation, thus potentially inhibiting CSR especially for smaller non-listed, but nevertheless incorporated, firms and that the health and safety environment and environmental management systems components of contractors' policies are influenced by the legislated requirements in Hong Kong.

This research has added to knowledge in the following areas

1 It is the first industry wide, state-wide analysis of the implementation of CSR activities across a range of corporate sizes within a single industry and therefore it is the first research which can categorically confirm based on empirical research that small companies are not little big companies when it comes to implementing CSR.

2 It has identified in general terms the most relevant and least relevant core subjects and issues in ISO 26000 to the Hong Kong Construction Industry, which may be generalisable to other construction industries.

It is suggested that this research has developed a now-proven research instrument in the survey questionnaire form for assessing what core issues and core subject might be relevant to a company or industry. Future research would be to apply this questionnaire to another industry and in another location, across a broad range of corporate sizes to confirm the findings of this research that, in CSR activities, "size is the only thing that matters".

\section{Acknowledgement}

The Authors would like to thank the Hong Kong Construction Association for its support of this research.

\section{References}

ABS 1999, Small and medium enterprises business growth and performance survey Australia, viewed 13 November 2012

http://www.abs.gov.au/ausstats/abs@.nst/DetailsPage/8141.01997-98?OpenDocument

Ahmad, NMB 2011, 'The Economic Globalisation And Its Threat To Human Rights', International Journal of Business and Social Science, 2 (19).

Carroll, AB 1999, 'Corporate social responsibility', Business and Society, 38 (3), 268-295.

Chaudhri, VA 2006, 'Organising Global CSR', Journal of Corporate Citizenship, 23, 39-51.

Coakes, S \& Steed, L 2007, SPSS 14.0 Analysis without Anguish, John Wiley and Sons, Australia.

Cochran, PL 2007, 'The evolution of corporate social responsibility', Business Horizons, $\mathbf{5 0}$ (6), 449-454.

Coelho, PRP,McClure, JE \& Spry, JA 2003, 'The social responsibility of corporate management: A classical critique', Mid - American Journal of Business, 18 (1), 15-24.

Diao, Y 2010, Research on International Standardization of Corporate Social Responsibility,

Barnes, L R and Croker, N (2013) 'The relevance of the ISO26000 social responsibility issues to the Hong Kong construction industry', Australasian Journal of Construction Economics and Building, 13 (3) 37-50 
EC 2003, The New SME Definition; User Guide and Model Declaration, European Commission, viewed 24 April 2009

http://ec.europa.eu/enterprise/enterprise policy/sme definition/index en.htm

Fellows, R \& Liu, A 2003, Research Methods for Construction 2edn, Blackwell Science, Oxford.

Gill, RWT \& Leinbach, LJ 1983, 'Corporate Social Responsibility in Hong Kong', California Management Review, 25 (2) 107-123.

Green, SD 2007, 'The evolution of corporate social responsibility in construction', in M Murray \& A Dainty (eds), Corporate Social Responsibility in the Construction Industry, Taylor and Francis Books Ltd., London.

Hair, JFJ, Babin, B, Money, AH \& Samouel, P 2003, Essentials of Business Research Methods, John Wiley and Sons, Inc, Hoboken.

Hatcher, M 2003, 'New corporate agendas', Journal of Public Affairs (14723891), 3 (1), 32.

Hillebrandt, P 2000, Economic Theory and the Construction Industry 3edn, McMillan Press Limited, London.

HKCA 2012, Hong Kong Construction Association, viewed 23 November 2012 http://www.hkca.com.hk/

HKCIC 2012, Construction Industry Council Voluntary Registration Scheme, viewed 23 November 2012 http://www.hkcic.org/eng/main.aspx

HKFEMCL 2012, The Hong Kong Federation of Electrical and Mechanical Contractors Limited, viewed 23 November 2012 http://www.hkfemc.org/

HKGDevB 2012, List of Approved Contractors, viewed 23 November 2012 http://www.devb.gov.hk/en/construction sector matters/contractors/index.html

HKGov 2013, Facts about Hong Kong, viewed 13 January 2013 http://www.gov.hk/en/about/abouthk/facts.htm

HKSARCSD 2013a, Key statistics on business performance and operating characteristics of the building, construction and real estate sectors in 2011 [29.11.2012], HKSAR, viewed 11 January 2013

http://www.censtatd.gov.hk/press release/pressReleaseDetail.jsp?charset|D=1\&pressRID=3 $\underline{057}$

HKSARCSD 2013b, Report on the Quarterly Survey of Construction Output, Census and Statistics Department HKSAR, viewed 28 May 2013

HKTDC 2013, Economy Research, viewed 13 January 2013 http://hong-kong-economyresearch.hktdc.com

HKYP 2012, Yellow Pages List of Construction Contractors, viewed 23 November 2012 http://www.yp.com.hk/iypbusiness e10/en/html/browsing search/browsecat result douinfo. aspx?basket id=19408\&category id=19430

ISO 2010, ISO 26000 - Guidance on social responsibility, International Organization for Standardiation; ISO copyright office, Geneva.

Jones, MT 2009, 'Disrobing the emperor: mainstream CSR research and corporate hegemony', Management of Environmental Quality, 20 (3), 335.

Jones, P,Comfort, D \& Hillier, D 2006, 'Corporate social responsibility and the UK construction industry', Journal of Corporate Real Estate, 8 (3), 134-150.

Knopf, J, Kahlenborn, W, Hajduk, T, Weiss, D, Feil, M, Fiedler, R \& Klein, J 2011, Corporate Social Responsibility: National Public Policies in the European Union, European Commission, European Union, viewed 28 December 2012

http://ec.europa.eu/social/main.jsp?langld=en\&catld=331\&newsld=1012\&furtherNews=yes

Barnes, L R and Croker, N (2013) 'The relevance of the ISO26000 social responsibility issues to the Hong Kong construction industry', Australasian Journal of Construction Economics and Building, 13 (3) 37-50 
Mauch, J, E. \& Birch, JW 1998, Guide to the Successful Thesis and Dissertation, 4 edn, Marcel Dekker, Inc., New York.

Murray, M \& Dainty, A 2007, 'Corporate social responsibility: Challenging the construction industry', in M Murray \& A Dainty (eds), Corporate Social Responsibility in the Construction Industry, Taylor and Francis Books Ltd., London.

O'Brien, M \& Al Soufi, A 1993, 'Electronic data interchange and the structure ot the UK construction industry', Construction Management and Economics, 11, 443-453.

Perrini, F 2006, 'SMEs and CSR Theory: Evidence and Implications from an Italian Perspective', Journal of Business Ethics, 67 (3), 305-316.

Perrini, F,Russo, A \& Tencati, A 2007, 'CSR Strategies of SMEs and Large Firms. Evidence from Italy', Journal of Business Ethics, 74 (3) 285-300.

Petrovic-Lazarevic, S 2008, 'The development of corporate social responsibility in the Australian construction industry', Construction management and Economics, 26 (2), 93-101.

Rowlinson, S 2007, 'Corporate social responsibility in Hong Kong and the Asia Pacific construction industry', in M Murray \& A Dainty (eds), Corporate Social Responsibility in the Construction Industry, Taylor and Francis Books Ltd., London.

Russo, A \& Perrini, F 2010, 'Investigating Stakeholder Theory and Social Capital: CSR in Large Firms and SMEs', Journal of Business Ethics, 91 (2), 207-221.

Studer, S, Tsang, S, Welford, R \& Hills, P 2008, 'SMEs and Voluntary Environmental Initiatives: A Study of Stakeholders' Perspectives in Hong Kong', Journal of Environmental Planning and Management, 51 (2), 285-301.

Tang, HY-y 2001, Construct for Excellence, Construction Industry Review Committee of the HKSAR, Hong Kong.

Valmohammadi, C 2011, 'Investigating corporate social responsibility practices in Iranian organizations: an ISO 26000 perspective', Business Strategy Series, 12 (5), 257-263.

Votaw, D 1972, 'Genius Becomes Rare: A Comment on the Doctrine of Social Responsibility Pt. I', California Management Review, 15 (2), 25-31.

Welsh, JA \& White, JF 1981, 'A small business is not a little big business', Harvard Business Review, 59 (4), 18-27.

Yin, RK 2003, Case Study Research Design and Methods, 3 edn, Sage, Thousand Oaks, California. 